\title{
Konsep Desain Taman Makam Umat Kristiani Mumbul Kabupaten Badung Bali
}

\author{
Anisa Fitri ${ }^{1}$, Naniek Kohdrata ${ }^{1 *}$, Anak Agung Gede Sugianthara ${ }^{1}$ \\ 1. Prodi Arsitektur Lanskap, Fakultas Pertanian, Universitas Udayana, Indonesia 80232 \\ *E-mail: naniek_kohdrata@unud.ac.id
}

\begin{abstract}
Conceptual Design of Mumbul Christian Cemetery Badung Regency, Bali. Mumbul Christian Park has a land area of 1.6 ha and is located in a residential area. This study aims to identify the characteristics of the Mumbul Christian Cemetery, analyze and synthesize the potential and constraints on the site. This study used a survey method with data collection techniques through observation, interviews, and literature study. This study uses the Simonds (1996) design process stage method. The design process is divided into four stages, namely: Research, Analysis, Syntesis, and Design Plan. The division of space zones on the site is based on a concept that is in accordance with the meaning of death in Christianity, namely the zone of birth, the zone of temporary life and the zone of eternal life. The concept of Paradise of Memorial Park is the concept of a park as a garden of memories as well as a public space. The results of this research design can be used as a reference for thought and consideration in designing the landscape site and in other tomb garden areas.
\end{abstract}

Keywords: cemetery design, cemetery landscape, green open space

\section{Pendahuluan}

Pemakaman umum bukan hanya sekedar untuk berziarah. Berdasarkan Peraturan Menteri Pekerjaan Umum (PermenPU) 2008, makam merupakan Ruang Terbuka Hijau (RTH) yang memiliki fungsi ekologis yaitu sebagai daerah resapan air, tempat pertumbuhan berbagai jenis tanaman, pencipta iklim mikro serta tempat hidup burung serta fungsi sosial masyarakat disekitar seperti beristirahat dan sebagai sumber pendapatan. Pemakaman yang baik dan benar dapat mewujudkan sebuah pemakaman yang rapi, bersih, memiliki kesan memorial tinggi serta memberikan visual yang menarik. Taman Makam Umat Kristiani Mumbul Jimbaran (TMUKMJ) merupakan salah satu taman makam yang terletak di Jl. By Pass Ngurah Rai, Jimbaran, Kuta Selatan, Kabupaten Badung, Bali. Taman makam ini salah satu tempat persemayaman jenazah bagi umat Kristiani. Taman Makam Umat Kristiani Mumbul Jimbaran memiliki luas lahan seluas 1,6 ha dan berada di wilayah pemukiman warga Desa Adat Jimbaran Kecamatan Kuta Selatan, Kabupaten Badung, Provinsi Bali. Berdasarkan hasil observasi lapang ditemukan permasalahan pada tapak seperti ruang parkir dan ruang sirkulasi yang belum memadai serta visual tapak. Pembagian area parkir belum jelas antara mobil, motor, ambulance dan bus, sehingga sering kali kendaraan parkir tidak sesuai dengan tempatnya. Ruang sirkulasi jalan pada makam ini memiliki lebar 4,5 m yang digunakan sebagai jalur dua arah untuk kendaraan yang akan menuju dan meninggalkan krematorium, serta digunakan pula bagi pejalan kaki. Sampah yang berserakan dan tanaman liar dapat mengurangi nilai fungsi esetika pada tapak.

Berdasarkan permasalahan tersebut, diperlukan penataan ulang pada area parkir dan sirkulasi pejalan kaki maupun kendaraan sebagai upaya meningkatkan kualitas pelayanan yang nyaman dan tertib, selain itu diperlukannya penambahan tempat sampah dan pemangkasan ataupun penataan ulang untuk tanaman yang akan dipertahakan pada tapak. Penambahan tempat sampah diharapkan dapat meminimalisir sampah yang berserakan, sedangkan pemangkasan tanaman diharapkan dapat mengurangi bad view pada tapak. Penelitian ini bertujuan untuk mengetahui kondisi tapak dan menunjang kebutuhan kenyamanan bagi pengguna tapak serta menambah estetika tapak Taman Makam Umat Kristiani Mumbul, menganalisis dan membuat sintesis dari potensi dan kendala pada tapak. Penelitian ini dapat menjadi inspirasi bentuk konsep desain bagi pengelola Taman Makam Mumbul Kristiani Mumbul, Jimbaran maupun di kawasan taman makam lainnya. 


\section{Metode}

\subsection{Waktu dan Lokasi}

Penelitian ini dilakukan pada Taman Makam Umat Kristiani Mumbul Jimbaran Kuta Selatan, Kabupaten Badung, Bali. Penelitian dilakukan selama enam bulan yakni bulan November 2019 hingga Mei 2020. Peta lokasi penelitian dapat dilihat pada gambar 1.

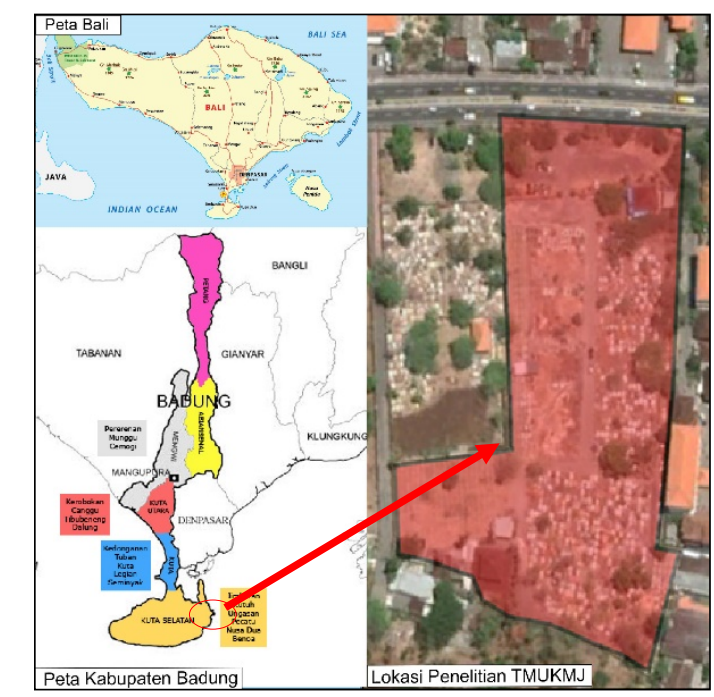

Gambar 1. Lokasi Penelitian (Google Earth, 2020)

\subsection{Alat dan Bahan}

Penelitian ini menggunakan alat berupa perangkat keras (hardware) seperti handphone berfungsi sebagai pengambil gambar, laptop sebagai pengolah data, dan meteran sebagai pengukur. Serta perangkat lunak (software) seperti Microsoft Word, Microsoft Excel, Autodesk AutoCAD, Sketch Up dan Photoshop. Bahan yang digunakan yaitu Lembar Wawancara tentang data aktivitas pada tapak.

\subsection{Metode Penelitian}

Metode penelitian menggunakan metode survei. Teknik pengumpulan yang digunakan adalah observasi, wawancara dan studi literatur. Observasi adalah metode pengumpulan data penelitian ini menggunakan pengamatan lapangan. Wawancara dilakukan untuk mengajukan pertanyaan kepada salah satu pengelola tapak. Studi literatur adalah melakukan pencarian data dengan cara pengumpulan data pustaka atau sumber tertulis untuk mencari referensi yang relevan dengan kasus atau permasalahan yang ditemukan, seperti buku, jurnal, artikel laporan penelitian dan situs-situs di internet.

Metode analisis data menggunakan dalam penelitian ini menggunakan metode analisis deskriptif kualitatif yang mengacu pada tahapan proses perancangan lengkap Simonds (1996). Proses perancangan dibagi ke dalam empat tahap, yaitu: research, analysis, syntesis, dan design plan. Penelitian ini dibatasi hingga hasil berupa konsep desain yang disertai dengan sejumlah gambar ilustrasi untuk mendukung penjelasan konsep desain.

\section{Hasil dan Pembahasan}

\subsection{Data dan Analisa Aspek Biofisik}

Identifikasi kondisi biofisik bertujuan untuk mengetahui kondisi Taman Makam Umat Kristiani Mumbul. Indikator yang diteliti pada kondisi biofisik ini adalah kondisi geografis, kondisi iklim, topografi dan kemiringan, tanah dan hidrologi, tanaman dan satwa, aksesibilitas dan sirkulasi, fasilitas dan utilitas serta visual tapak. Secara administratif Taman Makam Umat Kristiani Mumbul berada pada wilayah Kelurahan Jimbaran, Kecamatan Kuta Selatan, Kabupaten Badung, Provinsi Bali. Kelurahan Jimbaran memiliki luas 2.050 ha dengan ketinggian tempat antara 0-28 mdpl (BPS Badung, 2017). Taman Makam Umat Kristiani Mumbul memiliki luas lahan seluas 1,6 ha dan berada di wilayah pemukiman warga. Taman Makam Kristiani ini bukan 
hanya untuk sebagai tempat berziarah namun tapak juga sering digunakan untuk aktivitas selain berziarah. Pengunjung melakukan kegiatan berziarah di saat hari raya besar umat Kristiani seperti Hari Raya Natal dan Hari Paskah, sedangkan untuk hari-hari biasa bersifat pribadi atau sesuai keperluan keluarga seperti hari lahir almarhum dan tanggal meninggal almarhum.

Data Iklim dari BMKG (2017) pada tapak menunjukan bahwa suhu rata-rata setiap tahunnya yaitu sebesar $27,3^{\circ} \mathrm{C}$. Umumnya di wilayah tropis manusia akan cenderung merasa nyaman pada nilai $20-26^{\circ} \mathrm{C}$ dan sudah merasa tidak nyaman pada suhu di atas $27^{\circ} \mathrm{C}$ (Effendy et al. 2006). Untuk meminimalisir suhu udara yang tidak nyaman, dapat dilakukan dengan penanaman tanaman peneduh sebagai upaya untuk memanipulasi iklim mikro (Setyawati, 2008). Rata-rata curah hujan tahunan tapak mencapai 146,8 mm. Kelembaban udara rata-rata setiap tahunnya yaitu sebesar 77,8\% (BMKG, 2017). Struktur jalan yang belum baik saat curah hujan yang cukup tinggi dapat menyebabkan ketidaknyamanan pengunjung karena terdapat kubangan dan tapak menjadi licin ataupun berlumpur. Kondisi tersebut dapat diatasi dengan mengaplikasikan penutup tanah untuk melindungi permukaan.

Tapak memiliki kemiringan lereng antara 0-5\%. Elevasi terendah berada pada bagian barat dan elevasi tertinggi berada pada bagian Selatan (Gambar 2). Berdasarkan Booth (1983) dalam Nafar (2016), kemiringan lahan 1-5\% merupakan kategori kemiringan lahan yang ideal untuk dijadikan berbagai macam fungsi ruang tanpa perlu menghadapi permasalahan dalam membentuk muka lahan (grading). Dilihat dari topografi yang datar sehingga tapak baik digunakan sebagai tempat pemakaman.

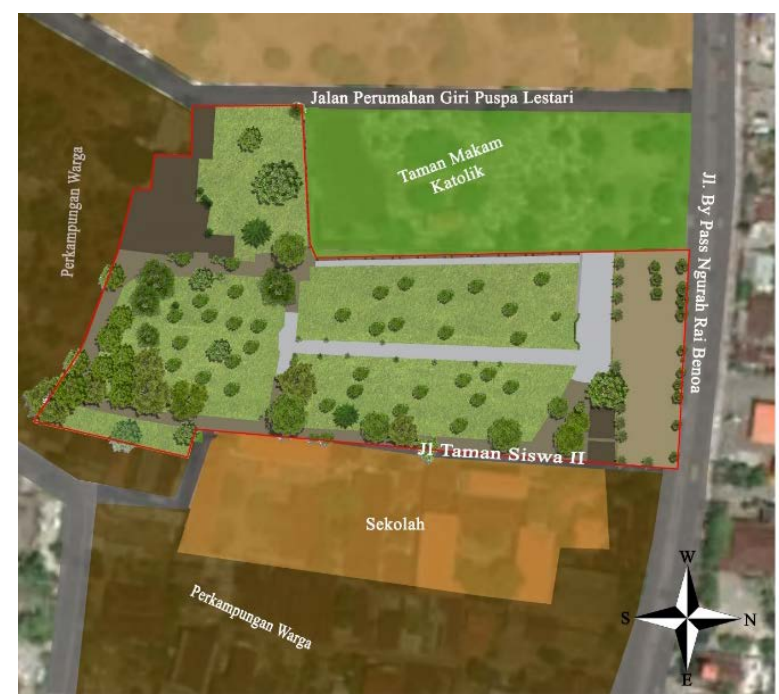

Gambar 2. Denah Orientasi Taman Makam Umat Kristiani Mumbul Jimbaran

Jenis tanah Kecamatan Kuta Selatan termasuk dalam jenis tanahmediteran dan termasukgolongan batuan formasi selatan. Tanah mediteran dikategorikan tanah yang tidak subur bagi tanaman karena tidak memiliki unsur hara. Penambahan unsur hara pada tanah dapat dilakukan dengan pemberian pupuk organik, selain itu pemilihan jenis tanaman juga disesuaikan dengan kondisi tapak tanah yang berkapur (Mursitantyo, 2015). Taman Makam Umat Kristiani Mumbul mendapatkan sumber air dari PDAM dan air sumur. Air tersebut digunakan untuk menyiram tanaman di tapak dan juga untuk keperluan sanitasi lainnya. Penyiraman tanaman dilakukan dengan penambahan alat springkel untuk mengefisiensi proses penyiraman tanaman pada tapak.

Tanaman pada tapak didominasi oleh tanaman kamboja (Plumeria rubra). Selain itu, terdapat juga tanaman yang ditemui tapak yang memiliki fungsi sebagai peneduh diantaranya yaitu Ketapang (Terminalia catappa), Bungur (Lagerstroemia speciosa), Tanjung (Mimusops elengi), Beringin (Ficus benjamina), Akasia (Acacia auriculiformis), Pohon Jati (Tectona grandis), Mimba (Azadirachta indica) dan Kersen (Muntingia calabura). Beberapa tanaman nantinya akan di diganti namun beberapa tanaman yang sesuai dengan manfaat pada tapak akan dipertahankan dan dilakukan pemangkasan. Peletakan dan penggunaan jenis tanaman akan disesuaikan berdasarkan fungsinya, karena sangat diperlukan untuk menciptakan suasana yang nyaman bagi pengunjung dan sebagai visualisasi di tapak. 
Tapak dapat diakses dengan menggunakan kendaraan, baik kendaraan roda empat maupun roda dua. Tapak dapat diakses lewat jalan lokal dan jalan kolektor untuk menuju tapak. Jalan kolektor adalah Jalan By Pass Ngurah Rai sebagai jalan utama menuju lokasi, sedangkan jalan lokal adalah Jalan Giri Puspa dan Jalan Taman Siswa II yang berbatasan dengan tapak. Taman Makam Mumbul Kristiani memiliki sejumlah fasilitas dan utilitas pendukung guna mengakomodasi aktivitas bagi pengunjung. Fasilitas yang tersedia di Taman Makam Mumbul Kristiani diantaranya berupa area parkir bagi kendaraan, signage, bangunan kantor administrasi, pos satpam dan bangunan krematorium.

Kondisi fasilitas yang terdapat pada tapak cukup baik. Utilitas yang ada pada tapak diantaranya saluran drainase yang cukup baik, sistem penerangan dan jaringan listrik. Akses untuk memasuki kawasan menggunakan satu jalur utama untuk semua kegiatan yang ada di tapak, akan tetapi jalur tersebut kurang memadai. Kondisi jalur sirkulasi untuk kendaraan pada tapak saat ini yaitu dengan lebar $4.5 \mathrm{~m}$. Kondisi demikian tidak memungkinkan adanya arus balik kendaraan untuk ambulan dan kendaraan pribadi roda empat. Sehingga dalam proses desain nantinya sirkulasi yang ada di dalam tapak akan dibuat berdasarkan kebutuhan yaitu untuk kendaraan roda empat, kendaraan bermotor dan juga pejalan kaki. Kenyamanan pengunjung atau pengguna tergantung pada fasilitas dan utilitas yang ada di tapak. Fasilitas dan utilitas yang ada cukup mendukung untuk kebutuhan pengguna namun ada beberapa fasilitas yang perlu di dikembangkan lagi, seperti tempat parkir, lampu penerangan tempat sampah dan rumah duka.

Tapak memiliki topografi dan kemiringan yang berbeda sehingga keadaan visual juga dipengaruhi oleh kondisi tersebut, dimana dapat mempengaruhi kondisi visual potensi (good view) dan kendala (bad view). Peta kondisi visual pada tapak dan sekitar tapak dapat dilihat pada Gambar 3.

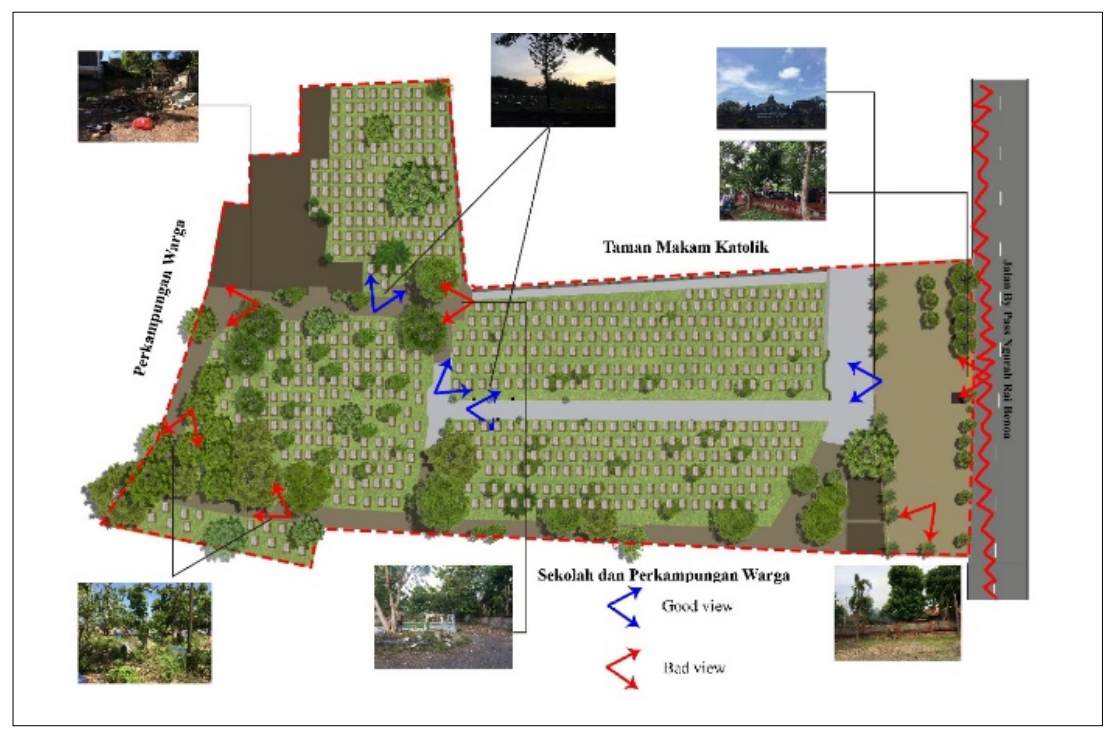

Gambar 3. Visual Tapak Penelitian

\subsection{Data dan Analisa Aspek Sosial}

Secara administrasi tapak pemakaman ini diperuntukkan bagi umat dari gereja-gereja Kristen khususnya yang ada di Denpasar, Kabupaten Badung, Kabupaten Gianyar, Kabupaten Bangli dan Kabapuaten Tabanan untuk pemakaman. Berdasarkan observasi dan wawancara kepada pihak pengelola secara umum krematorium pada tapak bisa digunakan oleh semua umat. Tapak sering dikunjungi saat proses pemakaman ataupun ziarah kubur pada siang dan sore hari. Tapak dikelola langsung oleh Yayasan Purna Bakti MPAG (Musyawarah Pelayanan Antar Gereja), namun sekarang MPAG berubah menjadi MPUK (Musyawarah Pelayanan Umat Kristen). Pengelola krematorium adalah Yasayan Kita.

Pengunjung melakukan kegiatan berziarah di saat hari raya besar umat Kristiani seperti Hari Raya Natal dan Hari Paskah, sedangkan untuk hari-hari biasa bersifat pribadi atau sesuai keperluan keluarga seperti hari lahir almarhum dan tanggal meninggal almarhum. Jumlah pengunjung untuk hari biasa sekitar 15 pengunjung, saat hari raya besar untuk perharinya kurang lebih 1000 pengunjung. 


\subsection{Sintesis}

Berdasarkan analisis pada aspek biofisik dan aspek sosial, diperoleh area yang dapat dikembangkan atau dimanfaatkan pada tapak. Beberapa hal yang akan dikembangkan pada kawasan Taman Makam Mumbul Kristiani yaitu ruang parkir, sirkulasi kendaraan, sirkulasi pejalan kaki dan penambahan rumah duka untuk memudahkan warga yang menggunakan rumah duka khususnya untuk yang tinggal di Bali selatan. Hal tersebut disebabkan karena rumah duka yang ada di Bali selatan belum tersedia sehingga akan membebankan biaya bagi yang membutuhkan rumah duka. Pada area penerimaan dikembangkan menjadi area parkir yang didesain menjadi dua pembagian ruang antara parkir kendaraan roda dua dan roda empat. Pada area timur tapak samping kantor admnistrasi dikembangkan menjadi rumah duka. Pengembangan tapak dapat dilihat pada Gambar 4.

Tabel 1. Hasil analisis dan sintesis pada tapak

\begin{tabular}{|c|c|c|c|}
\hline No & Aspek Biofisik & Analisis & Sintesis \\
\hline 1. & Lokasi dan batas tapak & $\begin{array}{l}\text { Kurangnya pembagian ruang area } \\
\text { pada tapak, khususnya pada area } \\
\text { parkir yang kurang memadai. }\end{array}$ & $\begin{array}{l}\text { Melakukan perancangan zonasi ruang } \\
\text { pada tapak. }\end{array}$ \\
\hline 2. & Iklim & $\begin{array}{l}\text { Curah hujan cukup tinggi saat musim } \\
\text { penghujan , membahayakan } \\
\text { pengunjung karena terdapat kubangan } \\
\text { dan tapak menjadi licin ataupun } \\
\text { berlumpur. }\end{array}$ & $\begin{array}{l}\text { Diperlukannya penutup tanah untuk } \\
\text { melindungi permukaan jalan yang licin } \\
\text { dan penutup tanah pada taman }\end{array}$ \\
\hline 3. & Topografi & $\begin{array}{l}\text { Kemiringan lahan yang datar tidak } \\
\text { memberikan kesan natural, } \\
\text { menciptakan kesan visual lanskap } \\
\text { yang monoton. }\end{array}$ & $\begin{array}{l}\text { Dibuat perubahan bentukan lahan dan } \\
\text { dengan menggunakan elemen lain } \\
\text { untuk mendefinisikan suatu ruang. }\end{array}$ \\
\hline 4. & Tanah & $\begin{array}{l}\text { Tanah mediteran dikategorikan tanah } \\
\text { yang tidak subur bagi tanaman karena } \\
\text { tidak memiliki unsur hara. }\end{array}$ & $\begin{array}{l}\text { Pemberian pupuk organik, selain itu } \\
\text { pemilihan jenis tanaman juga } \\
\text { disesuaikan dengan kondisi tapak } \\
\text { tanah yang berkapur. }\end{array}$ \\
\hline 5. & Tanaman & $\begin{array}{l}\text { Terdapat tanaman liar dan tanaman } \\
\text { yang tidak rapi sehingga mengurangi } \\
\text { nilai visual pada tapak. }\end{array}$ & $\begin{array}{l}\text { Melakukan perawatan, pemangkasan } \\
\text { pada beberapa vegetasi yang } \\
\text { mengurangi nilai visual. }\end{array}$ \\
\hline 6. & Aksesibilitas dan sirkulasi & $\begin{array}{l}\text { Akses untuk memasuki kawasan } \\
\text { menggunakan satu jalur utama untuk } \\
\text { semua kegiatan yang ada di tapak, } \\
\text { akan tetapi jalur tersebut kurang } \\
\text { memadai. }\end{array}$ & $\begin{array}{l}\text { Memaksimalkan ruang untuk sirkulasi } \\
\text { kendaraan pada tapak. }\end{array}$ \\
\hline 7. & Fasilitas dan utilitas & $\begin{array}{l}\text { Tempat untuk parkir roda dua kurang } \\
\text { memadai dan tidak jelas dimana } \\
\text { tempat parkir untuk roda dua. }\end{array}$ & $\begin{array}{l}\text { Memaksimalkan zona parkir } \\
\text { berdasarkan kebutuhan ruang parkir. }\end{array}$ \\
\hline 8. & Visual tapak & $\begin{array}{l}\text { Terdapat bad view pada tapak } \\
\text { sehingga mengurangi daya tarik } \\
\text { tapak. }\end{array}$ & $\begin{array}{l}\text { Mengoptimalkan lagi dengan } \\
\text { menggunakan elemen sesuai } \\
\text { kebutuhan pada tapak, sehingga dapat } \\
\text { merubah keadaan visual menjadi baik } \\
\text { (good view). }\end{array}$ \\
\hline
\end{tabular}

\subsection{Konsep Dasar}

Konsep dasar yang diterapkan pada taman makam adalah Paradise of Memorial Park, yakni sebuah konsep yang meningkatkan unsur keindahan dan memperhatikan kenyamanan tapak bagi pengguna maupun pengelola pada tapak penelitian. Konsep diambil dari kata paradise memiliki arti surga, memorial berarti peringatan dan park adalah taman. Konsep ini didasarkan dari arti kematian bagi umat Kristiani, dimana kematian menuju ke kehidupan yang kekal dan mulia di surga. Selain itu, konsep desain yang akan dirancang pada tapak akan melibatkan beberapa simbol yang berkaitan dengan umat Kristiani. 


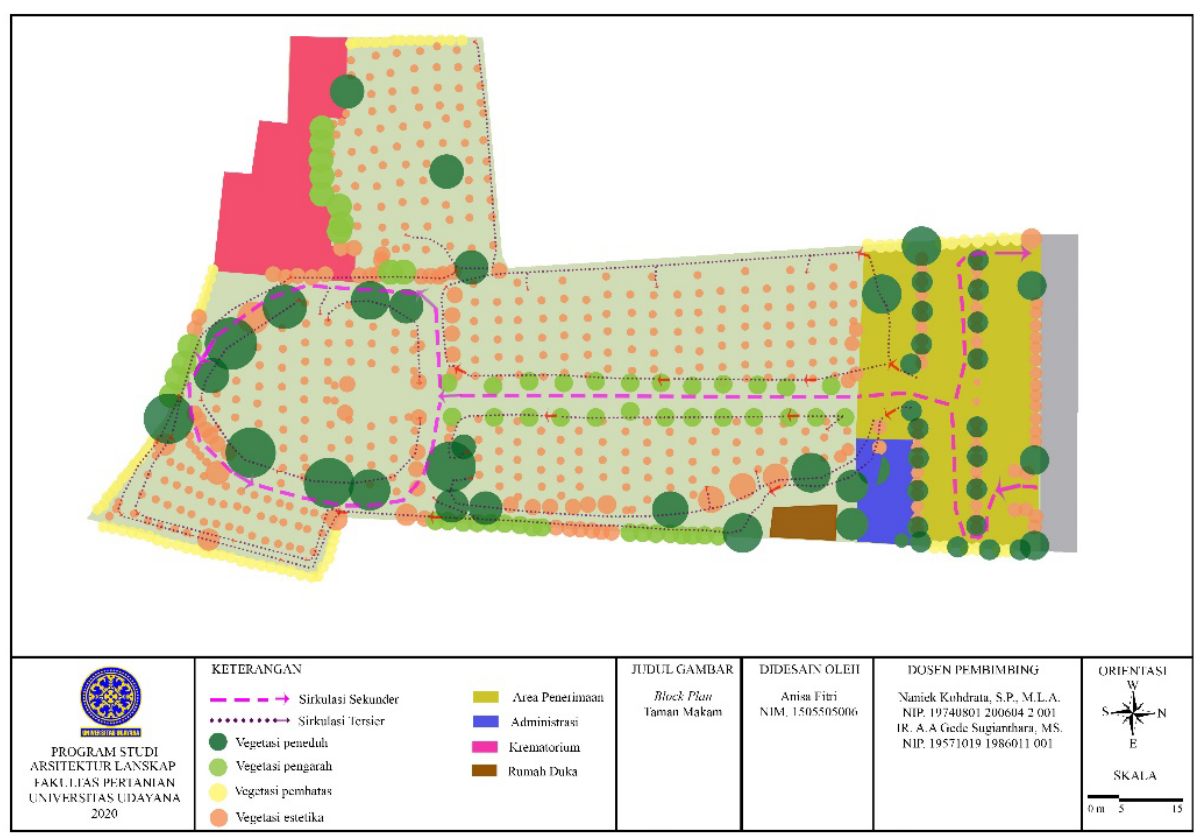

Gambar 4. Rencana Blok

\subsubsection{Konsep Ruang}

Pembagian zona ruang pada tapak berdasarkan konsep yang sesuai dengan makna kematian dalam agama Kristiani yaitu zona kelahiran, zona kehidupan sementara dan zona kehidupan kekal. Pada zona kelahiran sebagai area penerimaan, zona kehidupan sementara sebagai area pelayanan dan zona kehidupan kekal sebagai area utama pada tapak penelitian. Konsep ruang dapat dilihat pada Gambar 5.

Konsep sirkulasi yang akan diterapkan pada Taman Makam Umat Kristiani ini terdiri atas dua sirkulasi yaitu sirkulasi primer dan sirkulasi sekunder. Sirkulasi primer yaitu jalur yang ditujukan untuk pejalan kaki baik pengunjung maupun pengelola. Sirkulasi sekunder adalah jalur sirkulasi utama yang diperuntukkan bagi kendaraan ke dalam taman makam menuju bagian selatan tapak yang terdapat krematorium. Konsep sirkulasi dapat dilihat pada Gambar 6 .

Sirkulasi primer yaitu jenis sirkulasi yang didesain untuk pejalan kaki baik pengunjung maupun pengelola. Sirkulasi pejalan kaki memiliki lebar 1,5 m yang didesain dapat memuat dua pejalan kaki , jalur ini digunakan sebagai menghubungkan antar ruang pada tapak. Material yang digunakan dengan tekstur sedang yaitu paving block, atau grass block untuk membantu penyerapan air tanah sehingga tidak ada genangan air pada tapak. Sirkulasi sekunder yang merupakan jalan utama menuju tapak memiliki lebar \pm 6 meter untuk dua jalur kendaraan. Material yang digunakan yaitu material aspal atau concrete.

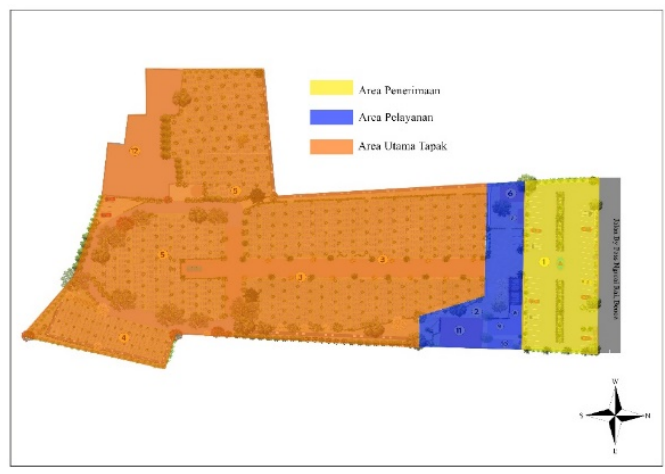

Gambar 5. Konsep Ruang Tapak Penelitian

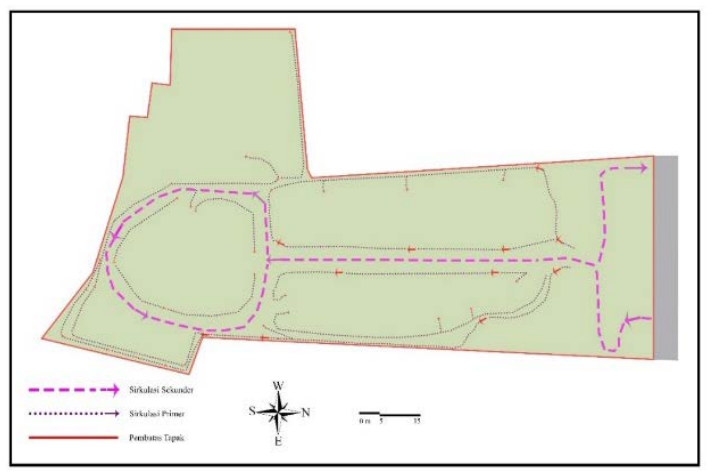

Gambar 6. Konsep Sirkulasi 
Rencana tata ruang untuk aktivitas dan fasilitas pada area taman makam merupakan pengembangan dari konsep tata ruang yang terbagi menjadi tiga ruang. Ketiga ruang tersebut yaitu zona kelahiran sebagai area penerimaan, zona kehidupan sementara sebagai area pelayanan dan zona kehidupan kekal sebagai area utama pada tapak penelitian, dapat dilihat pada tabel 2 .

Tabel 2. Rencana Ruang, Aktivitas dan Fasilitas

\begin{tabular}{|c|c|c|c|}
\hline Ruang & Area & Aktivitas & Fasilitas \\
\hline Ruang 1 & $\begin{array}{l}\text { Area Penerimaan } \\
\text { (Welcome Area) }\end{array}$ & $\begin{array}{l}\text { Area keluar masuk tapak, area } \\
\text { memarkir kendaraan, area } \\
\text { pertemuan terluar }\end{array}$ & $\begin{array}{l}\text { Akses dan keluar masuk, } \\
\text { parkir kendaraan, signage }\end{array}$ \\
\hline Ruang 2 & $\begin{array}{l}\text { Area Pelayanan } \\
\text { (Administrasi) }\end{array}$ & $\begin{array}{l}\text { Memperoleh informasi } \\
\text { ketersediaan makam dan } \\
\text { berziarah ke rumah duka }\end{array}$ & $\begin{array}{l}\text { Kantor administrasi, toilet, } \\
\text { rumah duka, florist shop, } \\
\text { pergola }\end{array}$ \\
\hline Ruang 3 & $\begin{array}{l}\text { Area utama makam, } \\
\text { penyimpanan abu dan } \\
\text { krematorium }\end{array}$ & $\begin{array}{l}\text { Tempat berziarah atau } \\
\text { mengunjungi makam, tempat } \\
\text { penghormatan berupa } \\
\text { penyimpanan abu pada lemari } \\
\text { dinding }\end{array}$ & $\begin{array}{l}\text { Taman makam, tempat } \\
\text { penyimpanan abu, signage, } \\
\text { krematorium, parkir } \\
\text { kendaraan bagi pengunjung } \\
\text { ke krematorium }\end{array}$ \\
\hline
\end{tabular}

Konsep tanaman pada tapak menerapkan tanaman yang memiliki fungsi estetika dan fungsi ekologis tanaman pada taman makam. Tanaman yang disarankan untuk diaplikasikan di tapak dimanfaatkan sebagai peneduh, estetika, pengarah, pembatas, dan pengikat debu. Rencana konsep tata hijau dikembangkan berdasarkan manfaat yang dapat diambil dari species tanaman pohon, semak, rambat, maupun ground cover. Daftar tanaman yang digunakan dalam tapak dapat dilihat pada Tabel 3.

Tabel 3. Daftar Tanaman yang digunakan dalam Tapak

\begin{tabular}{|c|c|c|c|}
\hline \multirow{2}{*}{ No } & \multicolumn{2}{|c|}{ Nama Tanaman } & \multirow{2}{*}{ Fungsi } \\
\hline & Nama Latin & Nama Lokal & \\
\hline \multicolumn{4}{|c|}{ Pohon } \\
\hline 1. & Acacia auriculiformis & Akasia & Estetika dan peneduh \\
\hline 2. & Bambusa vulgaris & Bambu kuning & Pembatas \\
\hline 3. & Delonix regia & Flamboyan & Peneduh dan estetika \\
\hline 4. & Ficus benjamina & Beringin & Peneduh \\
\hline 5. & Handroanthus chrysotrichus & Tabebuya & Estetika dan pengarah \\
\hline 6. & Lagerstroemia speciosa & Bungur ungu & Peneduh dan estetika \\
\hline 7. & Mimusops elengi & Tanjung & Peneduh \\
\hline 8. & Muntingia calabura & Kersen & Peneduh \\
\hline 9. & Plumeria rubra & Kamboja & Estetika \\
\hline 10. & Polyalthea longifolia & Glodokan tiang & Pengarah \\
\hline 11. & Roystonea regia & Palem raja & Estetika \\
\hline 12. & Terminalia catappa & Ketapang & Peneduh \\
\hline 13. & Terminalia mantaly & Ketapang kencana & Peneduh dan estetika \\
\hline 14. & Thuja occidentalis & Cemara kipas & Estetika \\
\hline \multicolumn{4}{|c|}{ Tanaman semak dan merambat } \\
\hline 15. & Dypsis lutescens & Palem kuning & Estetika dan pengarah \\
\hline 16. & Pennisetum purpureum & Rumput gajah & $\begin{array}{l}\text { Penutup tanah dan pengikat } \\
\text { debu }\end{array}$ \\
\hline 17. & Ruellia & Kencana ungu & Estetika dan pengikat debu \\
\hline 18. & Sphagneticola trilobata & Widelia & Estetika \\
\hline 19. & Thunbergia sp. & Thunbergia putih & Estetika \\
\hline 20. & Zoysia japonica & Rumput jepang & $\begin{array}{l}\text { Penutup tanah dan pengikat } \\
\text { debu }\end{array}$ \\
\hline
\end{tabular}


Konsep desain yang diajukan dari penelitian ini ditampilkan pada Gambar 7. Konsep desain taman makam yang memperhatikan unsur keindahan dan kenyamanan untuk pengguna maupun pengelola. Berdasarkan dari konsep dasar desain, yaitu paradise of memorial park, maka dalam konsep desain makam dengan nuansa taman ini juga mengakomodasi simbol-simbol yang akrab dengan umat Kristiani. Penggunaan simbol-simbol tersebut sebagai representasi keyakinan umat Kristiani.

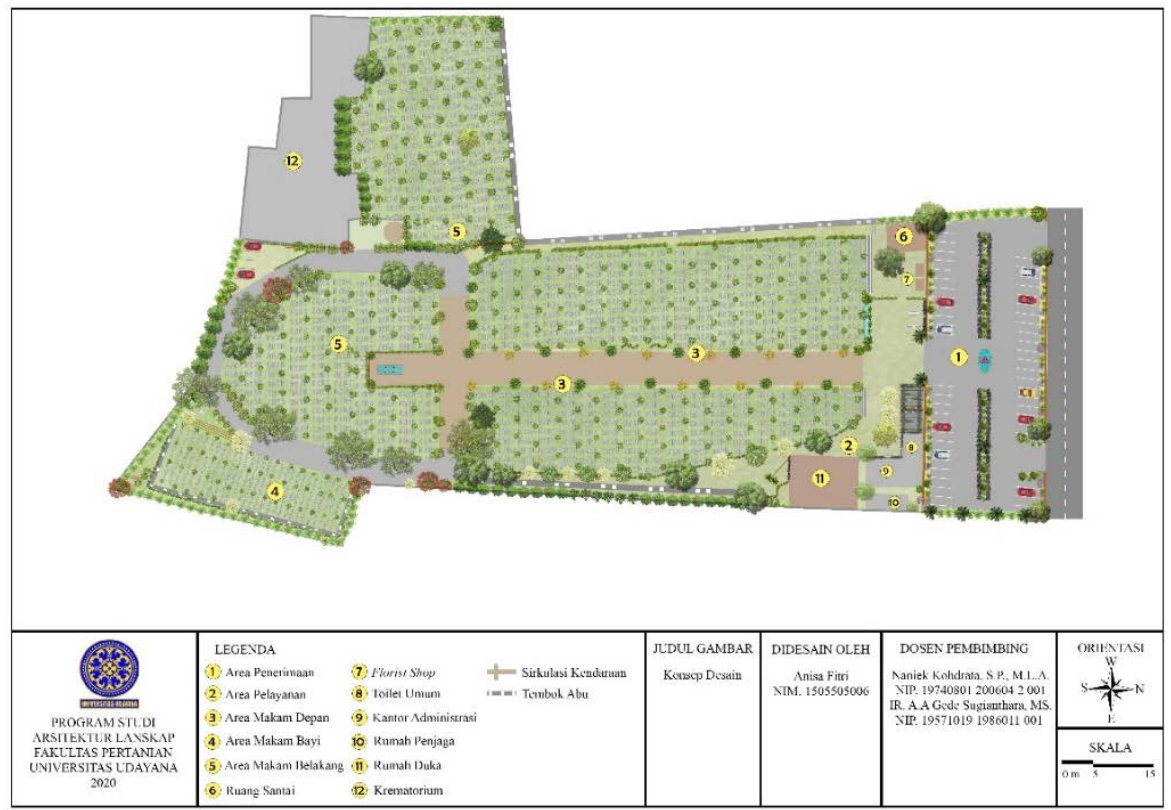

Gambar 7. Konsep Desain

Simbol yang diaplikasikan pada tapak yaitu bentuk Salib yang diterapkan pada main akses. Filosofi simbol Salib yaitu menjadi simbol identitas bagi umat Kristiani. Simbol Trinitas yang diterapkan dalam bentuk signage. Trinitas memiliki bentuk berupa tiga buah lekukan yang tidak terputus, saling menyambung, menyatakan kekekalan dan tritunggal. Signage berbentuk simbol trinitas ini diletakkan di welcome area. Bentuk signage ini sebagai penanda akses masuk-keluar tapak dan juga menjadi area pertemuan terluar dan parkir kendaraan. Area parkir kendaraan untuk roda empat memiliki luas $1.468 \mathrm{~m}^{2}$ yang dapat memuat 20 mobil. Kendaraan roda empat akan menggunakan tipe parkir $90^{\circ}$, lebar parkir mobil dengan tipe $90^{\circ}$ berkisar $3 \mathrm{~m}$ dan panjangnya adalah $6 \mathrm{~m}$. Sedangkan area parkir kendaraan untuk roda dua memiliki luas $32 \mathrm{~m}^{2}$ yang dapat memuat 18 motor, dengan memiliki lebar parkir 0,8 m. Akses masuk dan akses keluar tapak dibedakan untuk memperlancar sirkulasi kendaraan. Ilustrasi welcome area dapat dilihat pada gambar 8.
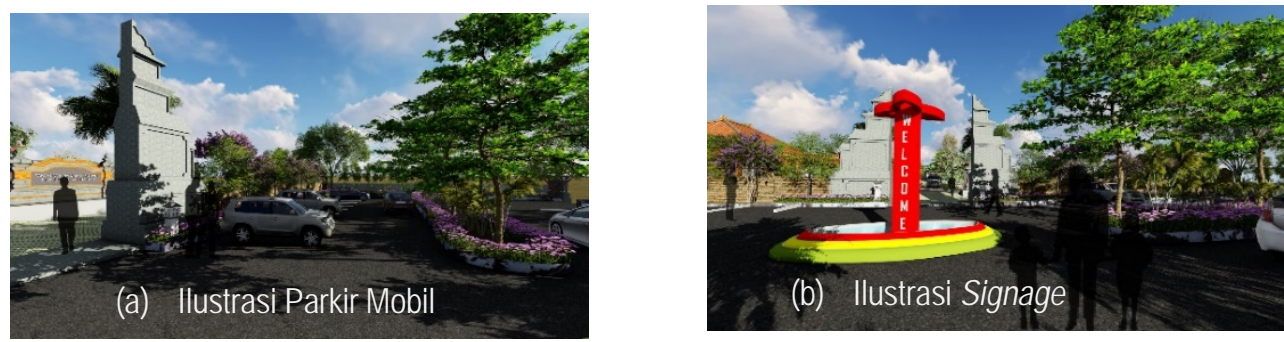

Gambar 8. Ilustrasi welcome area

Area pelayanan merupakan ruang untuk aktivitas melayani pengguna tapak seperti melakukan proses administrasi. Pada area ini terdapat kantor administrasi, toilet dan rumah duka. Kantor administrasi mempertahankan desain eksisting, sedangkan rumah duka di rancang sesuai konsep dasar. llustrasi fasilitas yang terdapat pada area pelayanan dapat dilihat pada gambar 9 . 

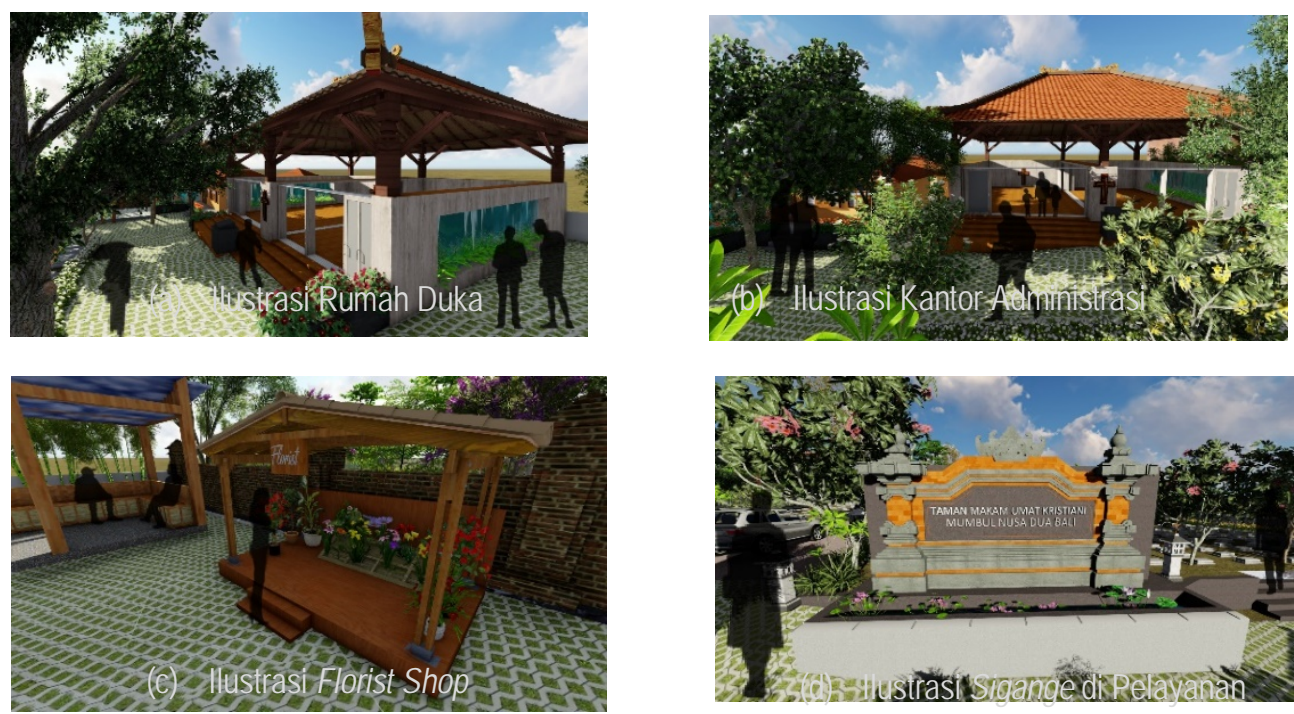

Gambar 9. Ilustrasi fasilitas yang terdapat di Area Pelayanan

Pada area tapak penelitian terdapat dua bagian makam yaitu makam umum dan makam bayi. Setiap lubang pada makam umum terdapat empat tingkat tempat jenazah dan untuk makam bayi ada delapan tingkat tempat jenazah bayi. Makam bayi terletak di bagian timur pada tapak. Selain itu, pada area ini juga terdapat tempat untuk penyimpanan abu yang diletakkan pada rak tembok tertutup. Adapun fasilitas yang terdapat di area ini diantaranya tempat istirahat berupa tempat duduk, art wall quotes di setiap dinding tembok penyimpanan abu dan tanaman yang menonjolkan kesan estetika. Adanya art wall quotes pada tapak diharapkan pengunjung selalu ingat akan mendapatkan berkah dari Tuhannya dan mereka juga akan selalu ingat akan dosa-dosa mereka. Ilustrasi fasilitas yang terdapat pada area makam utama dapat dilihat pada gambar 10.
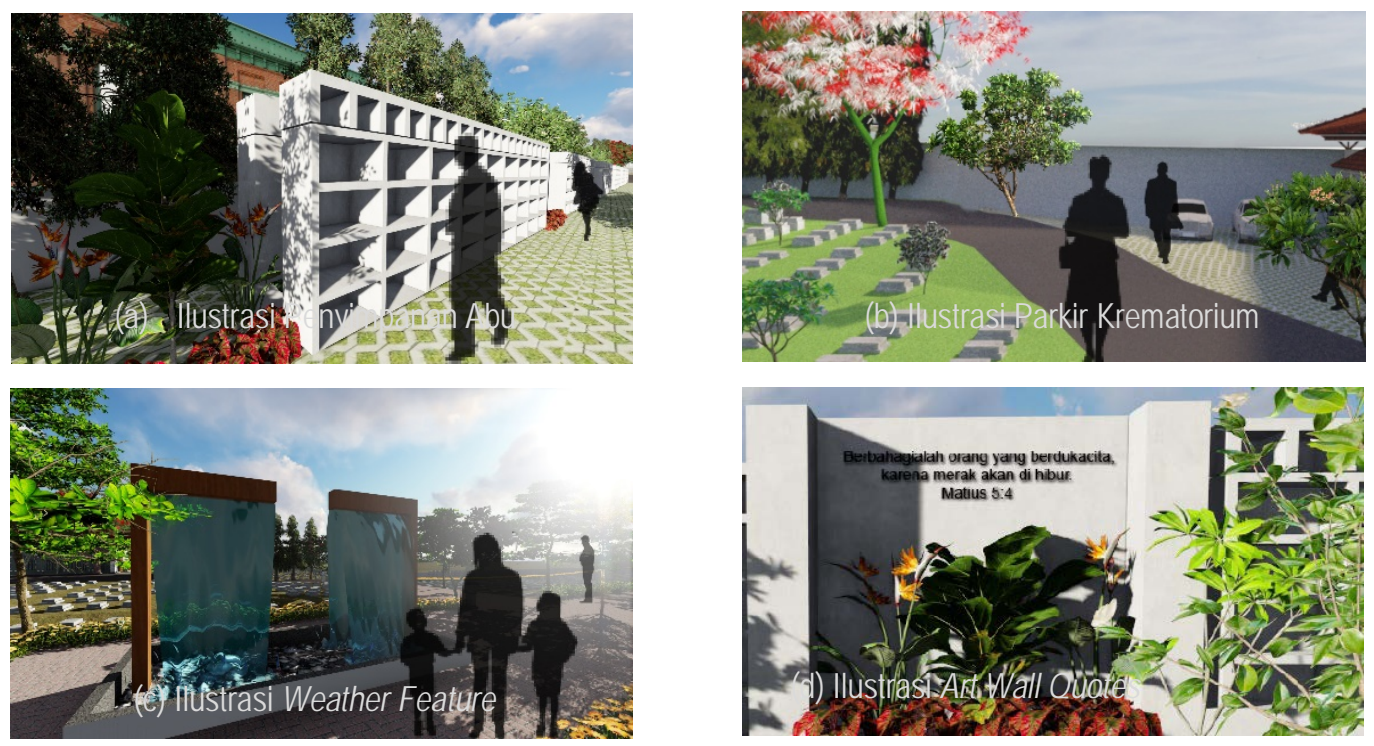

Gambar 10. Ilustrasi fasilitas yang terdapat di Area Makam Utama 


\section{Simpulan}

Taman Makam Umat Kristiani Mumbul Jimbaran memiliki karakter landform yang datar. Konsep dasar penelitian ini adalah Paradise Of Memorial Park. Konsep ini bertujuan untuk merepresentasikan kepercayaan umat Kristiani akan paradise sebagai dunia lain setelah kematian. Selain itu dengan tema memorial park, maka konsep ini bermaksud untuk menghadirkan keindahan dan kenyamanan bagi pengguna maupun pengelola sebagaimana fungsi sebuah taman. Paradise memiliki arti surga, memorial berarti peringatan dan park adalah taman. Rencana tata ruang pada area taman makam merupakan pengembangan dari konsep tata ruang yang terbagi menjadi tiga ruang. Ketiga ruang tersebut yaitu zona kelahiran sebagai area penerimaan, zona kehidupan sementara sebagai area pelayanan dan zona kehidupan kekal sebagai area utama pada tapak penelitian.

\section{Daftar Pustaka}

Badan Meteorologi, Klimatologi, dan Geofisika (BMKG). (2017). Pelayanan Jasa Informasi Klimatologi. Balai Besar Badan Meteorologi Klimatologi dan Geofisika Wilayah III. Denpasar.

Booth NK. (1983). Basic Elements of Landscape Architecture Design. Waveland Inc. New York.

Dinas Pertamanan dan Permakaman. (1999). Laporan Magang dan Pelatihan Tentang Wawasan Manajemen dan Teknik Tata Pemakaman di DKI Jakarta, Surabaya.

Effendy S, Bey A, Zain AFM, Santosa I. (2006). Peranan Ruang Terbuka Hijau dalam Mengendalikan Suhu Udara dan Urban Heat Island Wilayah JABOTABEK. J Agromet Indonesia 20(1):23-33.

Menteri Pekerjaan Umum. (2008). Peraturan Menteri Pekerjaan Umum Nomor 05 Tahun 2008 Tentang Pedoman Penyediaan Dan Pemanfaatan Ruang Terbuka Hijau Di Kawasan Perkotaan. Jakarta.

Mursitantyo, A., Suarbawa, K. N., \& Septiadhi, A. (2015). Analisis Efek Tapak Lokal Dari Geologi Tanah Di Badung Selatan Dan Kota Denpasar Dengan Survei Mikrotremor (Studi Kasus Gempa Bumi Nusadua, 13 Oktober 2011). 1-10. Retrieved from https://ojs.unud.ac.id/index.php/buletinfisika/article/view/30588

Nafar, S. (2016). Desain Ekologis Taman Koleksi Pakis Berbasis Sistem Klasifikasi Bioregion Di Ecopark, Cibinong Science Center - Botanic Gardens. S.P. Skripsi (tidak dipublikasikan) Institut Pertanian Bogor.

Setyawati DL. (2008). Iklim Mikro dan Kebutuhan Ruang Terbuka Hijau di Kota Semarang. J Manusia dan Lingkungan. 15(3): 125-140.

Simonds JO. (1996). Landscape Architecture: A Manual of Site Planning and Design. Graw-Hill Book Co. New York. 